\title{
Digeneans and acanthocephalans of birds from Formosa Province, Argentina
}

\author{
L. I. LUNASCHI, F. B. DRAGO, R. DRAGHI
}

Laboratorio de Helmintología, División Zoología Invertebrados, Museo de La Plata, Paseo del Bosque S/No 1900 La Plata, Buenos Aires, Argentina, E-mail: lunaschi@fcnym.unlp.edu.ar

\section{Article info}

Received July 3, 2014 Accepted October 7, 2014

\begin{abstract}
Summary
The aim of this paper is to increase the knowledge on the diversity of digenean parasites from birds collected in northeastern Argentina. The helminthological survey of four bird species revealed the presence of five digenean species and one acanthocephalan species. The digeneans, Lyperorchis lyperorchis Travassos, 1921 and Edietziana serrata (Diesing, 1850) from Aramus guarauna (L.); Nephrostomum limai Travassos, 1922 from Syrigma sibilatrix (Temminck); Athesmia heterolecithodes (Braun, 1899) from Theristicus caudatus (Boddaert) and Cariama cristata (L.); Stomylotrema vicarium Braun, 1901 from T. caudatus, and the acanthocephala Centrorhynchus guira Lunaschi \& Drago, 2010 from T. caudatus, were recorded. Lyperorchis inexpectabilis Digiani, 1997 is synonimized with $L$. lyperorchis. The findings of $E$. serrata and $N$. limai constitute new geographical records. Theristicus caudatus is reported as a new definitive host of $A$. heterolecithodes, $S$. vicarium and $C$. guira, and Cariama cristata of $A$. heterolecithodes. The relationships between host diet and parasite fauna are discussed.

Keywords: Lyperorchis lyperorchis; Edietziana serrata; Nephrostomum limai; Athesmia heterolecithodes; Stomylotrema vicarium; Centrorhynchus guira
\end{abstract}

\section{Introduction}

In the course of a parasitological survey carried out on birds from Formosa province, Argentina, were analyzed the helminths found in the Buff-necked Ibis, Theristicus caudatus (Boddaert) (Pelecaniformes, Threskiornithidae), in the Whistling Heron, Syrigma sibilatrix (Temminck), (Pelecaniformes, Ardeidae), in the Limpkin, Aramus guarauna (L.), (Gruiformes, Aramidae), and the Redlegged Seriema, Cariama cristata (L.) (Cariamiformes, Cariamidae). Theristicus caudatus, S. sibilatrix and C. cristata are exclusively Neotropical birds, and $A$. guarauna reaches also the $\mathrm{Ne}$ arctic Region, in the states of Florida and Georgia. In spite of their wide geographical distribution, the most part of parasitological studies in these bird species were carried out in Brazil (see Table 1). Particularly in Argentina, three of them were reported as definitive hosts of digeneans: T. caudatus from La Plata Zoological Garden, Buenos Aires Province, was found parasitized by Patagifer consimilis Dietz, 1909 (Echinostomatidae); A. guarauna from Buenos Aires Province by Lyperorchis inexpectabilis Digiani, 1997 (Echinostomatidae) and C. cristata from Formosa Province by Strigea inflecta Lunaschi \& Drago, 2012 (Strigeidae) and Brachylaima yupanquii Freitas, Kohn \& Ibáñez, 1967 (Brachylaimidae) (Boero \& Led, 1968; Digiani, 1997; Lunaschi \& Drago, 2012).

The aim of this paper is to increase the knowledge on the diversity of helminths parasites of birds from northeastern Argentina.

\section{Materials and Methods}

Eight birds, C. cristata $(n=2) ; A$. guarauna $(n=1) ; S$. sibilatrix $(n=4)$ and T. caudatus $(n=1)$, were shot between 2009 and 2012 in La Marcela farm (261' $35^{\prime \prime} S$; $\left.59^{\circ} 08^{\prime} 38^{\prime \prime W}\right)$, Pirané, Formosa Province, Argentina, with the authorization of Ministerio de la Producción, Dirección de Fauna y Parques of Formosa Province. These species are considered as residents in the study area, with records for all months of the year, and evaluated as Least Concern (LC) by the International Union for Conservation of Nature (IUCN) (Di Giacomo, 2005).The birds were dissected in the field and the gastrointestinal tract was immediately examined. The digeneans were removed, and live adults were comprised and fixed in $5 \%$ hot formalin, stored in $70 \%$ ethanol, stained with a $1: 6$ dilution in $96 \%$ ethanol of hydrochloric carmine, dehydrated 
Table 1. Check-list of helminths reported in the Limpkin, Buff-necked lbis, Red-legged Seriema and Whistling Heron in Neotropical Region

\begin{tabular}{|c|c|c|c|}
\hline Hosts & Parasitic species & Country & Source \\
\hline \multirow[t]{14}{*}{ Aramus guarauna } & Digenea & & \\
\hline & Lyperorchis lyperorchis & Brazil & Travassos (1921, 1922, 1928); Viana (1924) \\
\hline & & USA & Conti et al. (1985) \\
\hline & & Argentina & Digiani (1997), present study \\
\hline & Edietziana serrata & Brazil & Dietz (1910); Travassos (1922); Travassos et al. (1969) \\
\hline & & Venezuela & $\begin{array}{l}\text { Lutz (1928); Caballero \& Díaz-Ungría (1958); } \\
\text { Nasir \&Díaz (1972) }\end{array}$ \\
\hline & & Cuba & Pérez Vigueras $(1944,1956)$ \\
\hline & & USA & Conti et al. (1985) \\
\hline & Lyperosomum sinuosum & Brazil & Noronha et al. (2009) \\
\hline & $\begin{array}{l}\text { Echinostomatidae } \\
\text { Nematoda }\end{array}$ & USA & Conti et al. (1985) \\
\hline & Amidostomum acutum & USA & Conti et al. (1985) \\
\hline & Strongyloides sp. & USA & Conti et al. (1985) \\
\hline & $\begin{array}{l}\text { Syncuaria calcarata } \\
\text { Cestoda }\end{array}$ & Brazil & Yamaguti (1961) \\
\hline & $\begin{array}{l}\text { Chimaerula wodlandi } \\
\text { Diaenea }\end{array}$ & Brazil & Georgiev \& Vaucher (2000) \\
\hline \multirow{9}{*}{ Theristicus caudatus } & Strigea vaginata & Colombia & Dubois (1981) \\
\hline & Strigea bulbosa & Brazil & Travassos et al. (1969) \\
\hline & Patagifer consimilis & Argentina & Boero \& Led (1968) \\
\hline & & Brazil & Travassos et al. (1969) \\
\hline & Echinostoma necopinum & Brazil & Travassos et al. (1969) \\
\hline & $\begin{array}{l}\text { Stomylotrema sp. } \\
\text { Nematoda }\end{array}$ & Brazil & Travassos \& Freitas (1940); Travassos et al.(1969) \\
\hline & Tetrameres (T.) spirospiculum & Brazil & Magalhaes Pinto \& Vicente (1995) \\
\hline & Capillaria sp. & Brazil & Vicente et al. (1995a) \\
\hline & Porrocaecum heteropterum & Brazil & Digiani \& Sutton (2001) \\
\hline \multirow[t]{12}{*}{ Cariama cristata } & Digenea & & \\
\hline & Strigea inflecta & Argentina & Lunaschi \& Drago (2012) \\
\hline & Strigea vaginata & Brazil & Travassos et al. (1969) \\
\hline & Brachylaima yupanquii & Argentina & Lunaschi \& Drago (2012) \\
\hline & $\begin{array}{l}\text { Athesmia heterolecithodes } \\
\text { Nematoda }\end{array}$ & Brazil & Travassos et al. (1969) \\
\hline & Ascaridia pterophora & Brazil & Freitas \& Ibáñez (1965); Cristofaro \& Feijo (1976) \\
\hline & Subulura allodapa & Brazil & Barreto (1919); Cristofaro \& Feijo (1976) \\
\hline & Oxyspirura brevipenis & Brazil & Ransom (1904) \\
\hline & $\begin{array}{l}\text { Oxyspirura altensis } \\
\text { Acanthocephala }\end{array}$ & Brazil & Vicente et al. (1995b) \\
\hline & $\begin{array}{l}\text { Oligacanthorhynchus taenioides } \\
\text { Cestoda }\end{array}$ & Brazil & Travassos (1917) \\
\hline & Idiogenes horridus & Brazil & Fuhrmann (1908); Schultz (1939) \\
\hline & $\begin{array}{l}\text { Davainea brachyrhyncha } \\
\text { Digenea }\end{array}$ & Brazil & Fuhrmann (1908) \\
\hline \multirow{7}{*}{ Syrigma sibilatrix } & Nephrostomum limai & Brazil & Travassos et al. (1969) \\
\hline & Amphimerus interruptus & Brazil & Arruda et al. (2001) \\
\hline & $\begin{array}{l}\text { Stomylotrema gratiosus } \\
\text { Nematoda }\end{array}$ & Brazil & Arruda et al. (2001) \\
\hline & Tetrameres sp. & Brazil & Vicente et al. (1995a) \\
\hline & Viktorocara sp. & Brazil & Vicente et al. (1995a) \\
\hline & Cheilospirura hamulosa & Brazil & Arruda et al. (2001) \\
\hline & Pelecitus sp. & Brazil & Arruda et al. (2001) \\
\hline
\end{tabular}


and mounted in Canada balsam. The acanthocephalans were collected alive, extended in distilled water prior to fixation, fixed in $5 \%$ formaldehyde, preserved in $70 \%$ ethanol, cleared in Amman's lactophenol and studied under a light microscope. Both techniques used are described in Langeron (1942). Unless otherwise stated, measurements are given in micrometers $(\mu \mathrm{m})$; the range is followed by the mean in parentheses. Drawings were made with the aid of a drawing tube. In the description of specimens the forebody is defined as the distance from the anterior end of body to the anterior border of the ventral sucker, and the hindbody from the posterior border of the ventral sucker to the posterior end of the body. The helminths were deposited at the Helminthological collection of the Museo de La Plata (MLP-He), and the birds were deposited at the Ornithological collection of the Museo de La Plata (MLP), La Plata, Argentina. Four paratypes MLP-He 3323/2 of $L$. inexpectabilis from A. guarauna were examined. The taxonomy of birds is given in accordance to Remsen et al. (2014).

\section{Results}

\section{Trematoda}

Family Echinostomatidae Looss, 1899

Subfamily Echinostomatinae Looss, 1899

Genus Lyperorchis Travassos, 1921

Lyperorchis lyperorchis Travassos, 1921 (Fig. 1)

Syn. Lyperorchis inexpectabilis Digiani, 1997

Description. (Based on 5 whole-mounted mature specimens) Body large, elongate and slender, with maximum width at level of testes. Forebody notably short, $8-13 \%(11 \%)$ of body length. Tegumental spines absent. Head collar indistinct, collar-spines not observed. Oral sucker subterminal, subglobular, smaller than ventral sucker. Ventral sucker muscular, spherical, in first third of body. Prepharynx absent. Pharynx muscular, transversely-oval, slightly smaller than oral sucker. Oesophagus long, sinuous. Intestinal bifurcation anterior to ventral sucker, at $6-10 \%$ (8 \%) of body length. Caeca long, reach to posterior extremity.

Testes 2, in tandem, tubular, contiguous or slightly overlapping one another. Post-testicular field short, $14-17 \%$ (16 \%) of body length. Cirrus-sac oval, between intestinal bifurcation and anterior margin of ventral sucker. Internal seminal vesicle large, tubular and coiled. Pars prostatica short. Everted cirrus not observed, apparently short. Genital pore median, posterior to intestinal bifurcation and located in a papillae-like elevation.

Ovary median, pretesticular, oval, separated from anterior testis by the ovary complex, at $48-56 \%$ (53\%) of body length. Laurer's canal short, surrounded by numerous cells, with a possible glandular origin. Mehlis' gland conspicuous, median, posterior to ovary. Metraterm similar in length to cirrus sac. Uterus long, intercaecal, greatly convoluted, filling pre-ovarian region up to the posterior margin of ventral sucker; uterine seminal receptacle conspicuous. Eggs numerous, small, with inconspicuous operculum, $76-93 \times 34-53(84-43)$. Vitelline follicles small, in 2 lateral extracaecal fields extending from post-acetabular region to posterior extremity, interrupted between ovary and anterior testis, and non-confluent in post-testicular region.

Excretory vesicle Y-shaped, with a long and chambered central stem, bifurcating posterior to the testes; excretory pore terminal.

\section{Taxonomic summary}

Host: Aramus guarauna (L.) (Syns. A. escolipoceus, A. scolopaceus) (Gruiformes, Aramidae) (Carau or Limpkin).

Infection site: cloaca.

Intensity of infection: 5 .

Voucher material: MLP-He 6603.

Comments: Lyperorchis lyperorchis was described and reported parasitizing the recto and/or cloaca of Limpkin from Brazil and USA, and the Whooping crane, Grus americana L. (Gruiformes, Gruidae), from USA (Travassos, 1921, 1922, 1928; Conti et al., 1985; Spalding et al., 1996). The specimens here studied are in full agreement with those described by Travassos (1921), except the cirrus-sac length (740 - 870 vs. $474-580)$ (see Table 2).

On the other hand, we examined the specimens of $L$. inexpectabilis (4 paratypes) collected by Digiani (1997) from the cloaca of a Limpkin from Buenos Aires Province, Argentina. Three of these specimens were immature and one had only thirteen eggs. The holotype was not available, and its measures were calculated from the published drawing. Their body length, testes length, and eggs were similar in size to the specimens described herein. The most important differences are given in the body width, size of suckers, ovary and pharynx, but the majority of the calculated proportions are coincident (Fo, Ov, T, Ae-Ov, Pt, Os/Ph and Vs/Os) (see Table 2).

Moreover, the main diagnostic feature given by Digiani (op. cit.) to differentiate $L$. inexpectabilis from $L$. Iyperorchis is the shape of testes, described as non-winding. However, the re-examination of the specimens of $L$. inexpectabilis leads us to conclude that the testicles are slightly sinuous, and due to its incomplete development, they have not reached the width that characterizes these organs in $L$. lyperorchis. This observation reveals that $L$. inexpectabilis should be considered synonymous with L. lyperorchis, and therefore, the geographical distribution of the species should be enlarged to Buenos Aires Province.

\section{Genus Edietziana Özdikmen, 2013}

Syn. Prionosoma Dietz, 1909

Edietziana serrata (Diesing, 1850) Özdikmen, 2013 (Figs. 2 - 3)

Syn. Prionosoma serratum (Diesing, 1850) Dietz, 1909

Description. (Based on 1 whole-mounted mature specimen) Body large, elongate, linguiform, with maximum width at level of testes, $19 \%$ of body length. Forebody notably short, $11 \%$ of body length. Lateral margins of hindbody pleated. Tegument armed with spines in postacetabular region. Head collar relatively small, armed with 45 spines $[(4)+7+9+7+(4)]$, rod-shaped, short, straight; angle spines markedly larger than lateral spines, dorsal spines in double row and lateral spines, apparently, in single row. Oral sucker subterminal, smaller than ventral sucker. Ventral sucker muscular, cup-shaped, with shallow cavity, in first fifth of body. Prepharynx not seen; pharynx muscular, longitudinally oval; oesophagus long. Intestinal bifurcation anterior to ventral sucker, at $8.3 \%$ of body length; caeca long, reach to posterior end of body.

Testes 2, in tandem, tubular, thin, undulating. Post-testicular field short, $19 \%$ of body length. Cirrus-sac oval, between intestinal bifurcation and anterior margin of ventral sucker. Internal seminal vesicle large and coiled. Pars prostatica and cirrus not observed. 

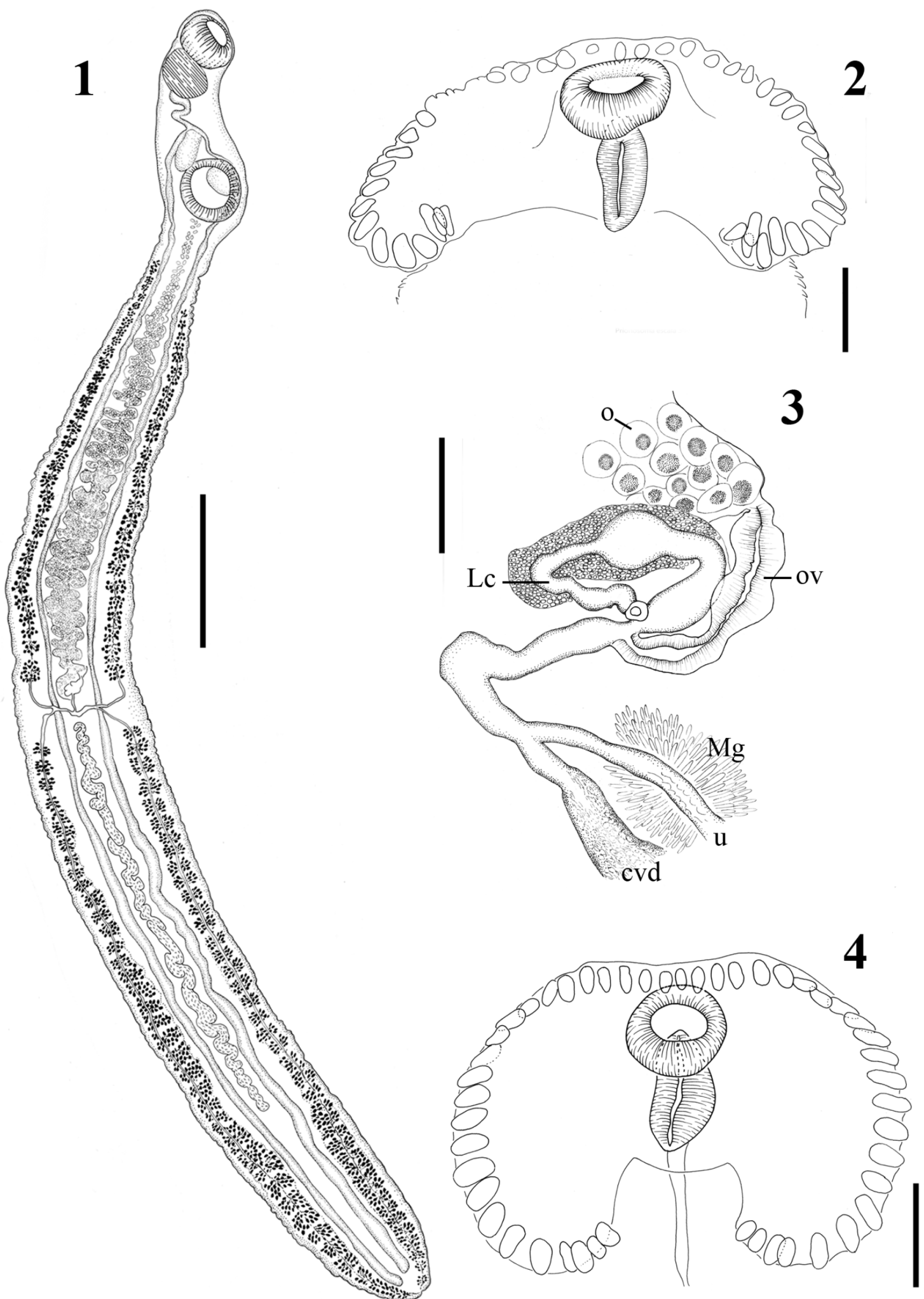

Figs. 1 - 4. Echinostomatids from Aramus guarauna and Syrigma sibilatrix from northeastern Argentina

Fig. 1. Lyperorchis lyperorchis. Entire worm, ventral view. Scale bar $=2 \mathrm{~mm}$. Figs. 2-3. Edietziana serrata. 2 . Head-collar. Scale bar $=500 \mu \mathrm{m}$. 3. Ovarian complex, dorsal view. Scale bar $=50 \mu \mathrm{m}$. Fig. 4. Nephrostomum limai. Head-collar. Scale bar $=200 \mu \mathrm{m}$. Abbreviations: cvd: common vitelline duct; Lc: Laurer's canal; Mg: Melhis' gland; o: ovary; ov: oviduct; u: uterus. 


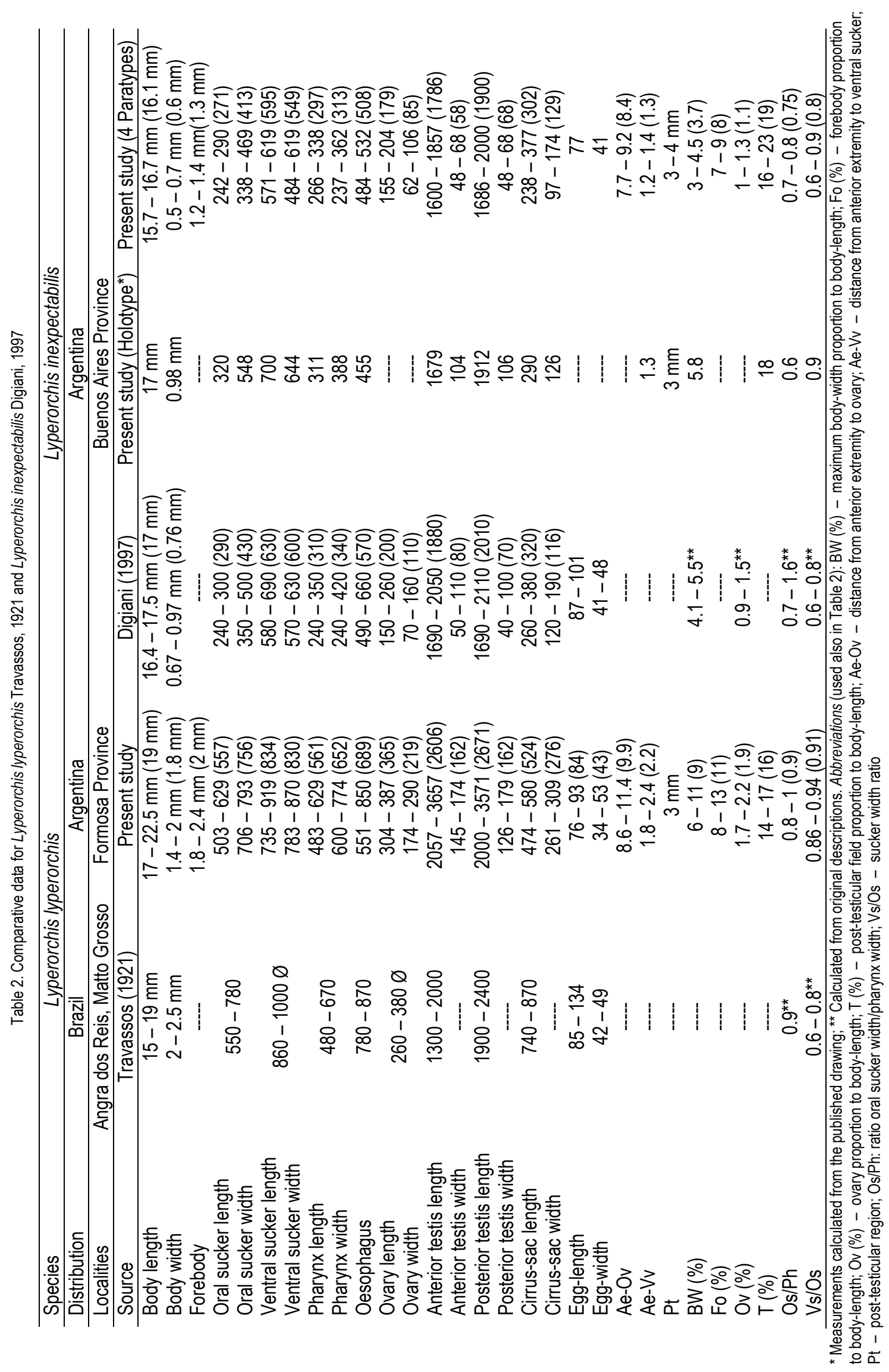


Genital pore median, posterior to intestinal bifurcation.

Ovary median, slightly post-equatorial, oval, separated from anterior testis by the ovary complex, at $54 \%$ of body length. Laurer's canal short. Mehlis' gland median, posterior to ovary. Metraterm not observed. Uterus long, greatly convoluted, intercaecal, filling pre-ovarian region of body up to the posterior margin of ventral sucker. Eggs numerous, small, $101 \times 48$. Vitelline follicles small, in 2 lateral fields, extending from immediately postacetabular region to the posterior end of body, and nonconfluent in post-testicular region. Excretory vesicle not observed; excretory pore terminal.

\section{Taxonomic summary}

Host: Aramus guarauna (L.) (Gruiformes, Aramidae). Infection site: small intestine.

Intensity of infection: 1.

Voucher material: MLP-He 6604.

Comments: Özdikmen (2013) proposed the name Edietziana for Prionosoma Dietz, 1909 because this generic name was preoccupied by a genus of hemipteran insects, and formulated new combinations for all species: Edietziana malacophilum (Pérez Vigueras, 1944), Edietziana pricei (Pérez Vigueras, 1944), Edietziana serrata (Diesing, 1850) (type species) and Edietziana zachwatkini (Sergienko, 1970).

In this paper we follow the taxonomy proposed by Kostadinova (2005), and consider valid the four species mentioned by Özdikmen. These species were found parasitizing the small intestine or cloaca of charadriiform, falconiform, gruiform, and pelecaniform birds from the Neotropical, Holarctic and Oriental Regions. At present, the only species reported in the Palaearctic region is $E$. zachwatkini. This species was described with $45-47$ spines in the collar head, and found parasitizing Rallus aquaticus L., Porzana parva (Scopoli) (Rallidae) and Gallinago gallinago (L.)(as Capella g.) (Scolopacidae) (Sergienko, 1970). Two other species are exclusively Neotropical, E. malacophilum described with 46 spines, parasitizing Rostrhamus sociabilis levis Friedmann (Accipitridae) from Cuba, and $E$. pricei, with an unknown number of spines in the collar head, found in Jacana spinosa violacea (Cory) (Jacanidae) from Cuba. Edietziana serrata, with 45 spines and a wider geographical distribution, was found in A. guarauna and $A$. guarauna pictus (Meyer) from Brazil, Venezuela, Cuba and Florida, Accipiter bicolor pileatus (Temminck) (Accipitridae) from Paraguay, and Egretta garzetta (L.) and Egretta intermedia (Wagler) (Ardeidae) from Taiwan (Travassos, 1922; Lutz, 1928; Caballero \& Diaz-Ungria, 1958; Conti et al., 1985; Masi Pallares \& Benítez Usher, 1972; Nasir \& Díaz, 1972; Noronha et al., 2009; Pérez Vigueras, 1944, 1956; Su \& Fei, 2000).

The specimens here described exhibit morphological and morphometric features similar to those described in A. guarauna from Brazil by Dietz (1910) and Travassos et al. (1969) (Table 3).

This finding represents the first record of the genus Edietziana in Argentina.

Subfamily Nephrostominae Mendheim, 1943

Genus Nephrostomum Dietz, 1909

Nephrostomum limai Travassos, 1922 (Fig. 4)

Description. (Based on 3 whole-mounted mature specimens)
Body elongate, $6.63-8.45(7.45)$ in total length, with maximum width at mid-uterine level $1.6-1.73(1.68)$. Forebody notably short, $670-770(730), 9-11 \%(10 \%)$ of body length. Oral sucker subterminal, small, 135 - $179 \times 184-188$ (153 - 185) surrounded by a large head collar with a wide ventral notch and a shallow dorsal depression, 532 - $580 \times 793$ - 870 (551 x 828), armed with 48 circumoral spines in a single row. Angle spines $2 x$ $4,50-74 \times 26-48(62 \times 37)$ are similar in size to lateral spines, $52-81 \times 21-29$ (67 x 25); the spines on dorsal depression are smaller, $48-57 \times 21-33$ (52 x 27). Ventral sucker deep, bellshaped, larger than oral sucker, 880 - 1064 x $338-1112$ (981 x 807). Prepharynx short; pharynx elongate-oval, $217-242 \times 116$ - 145 (225 x 127); oesophagus long, 314 - 435 (362) in length; intestinal bifurcation anterior to genital pore; caeca nearly reaching posterior extremity.

Testes small, elongate, lobed, in third quarter of body, anterior testis $774 \times 484$, posterior testis $822 \times 387$. Post-testicular field long, $24 \%$ of body length. Cirrus-sac oval, dorsal to ventral sucker, $435 \times 72$. Ovary transversely oval, smooth, median, equatorial, $362 \times 435$. Uterus long, with numerous intercaecal loops between ovary and ventral sucker. Vitelline follicles small, distributed laterally from the posterior margin of ventral sucker to posterior extremity. Excretory vesicle $\mathrm{Y}$-shaped; excretory pore dorso-subterminal. Eggs 106 - 110 x 39 - 57 (108 x 50).

\section{Taxonomic summary}

Host: Syrigma sibilatrix (Temminck) (Whistling Heron) (Pelecaniformes, Ardeidae).

Infection site: intestine.

Prevalence and mean intensity: $50 \%$ (2 of 4), 4. Voucher material: MLP-He 6787.

Comments: Nephrostomum limai was found parasitizing S. sibilatrix from Brazil (Travassos, 1922, 1938). In Argentina, the parasite was found naturally parasitizing the intestine of Bubulcus ibis (L.) (Ardeidae) from Río Negro Province (Sutton et al., 1982). The specimens here described exhibit morphological and morphometric features similar to those described for S. sibilatrix from Brazil by Travassos (1922), but smaller than those described later by Travassos (1938) and Sutton et al. (1982) (body 6.6 8.5 vs. $15,10.5-12$, respectively).

The finding of $N$. limai parasitizing $S$. sibilatrix from Formosa Province enlarges the geographical distribution of this parasite.

Family Dicrocoeliidae Looss, 1899

Subfamily Dicrocoeliinae Looss, 1899

Genus Athesmia Looss, 1899

Athesmia heterolecithodes (Braun, 1899) Looss, 1899

\section{Taxonomic summary}

Hosts: Theristicus caudatus (Boddaert) (Buff-necked lbis) (Pelecaniformes, Threskiornithidae); Cariama cristata (L.) (Red-legged Seriema) (Cariamiformes, Cariamidae).

Infection site: liver bile ducts.

Prevalence and mean intensity in C. cristata: 50 \% (1 of 2), 12 Intensity of infection in T. caudatus: 15.

Voucher material: C. cristata MLP-He 6788; T. caudatus MLP-He 6789 . 
Table 3.Comparative data for Edietziana serrata (Diesing, 1850) Özdikmen, 2013

\begin{tabular}{|c|c|c|c|c|c|}
\hline Source & Dietz (1910) & $\begin{array}{c}\text { Perez Vigueras } \\
(1944,1956)\end{array}$ & $\begin{array}{c}\text { Travassos et al. } \\
\text { (1969) }\end{array}$ & $\begin{array}{c}\text { Masi Pallarés \& Usher } \\
\text { (1972) }\end{array}$ & Present study \\
\hline Distribution & Brazil & Cuba & Brazil & Paraguay & Argentina \\
\hline Hosts & A. guarauna & A. guarauna pictus & A. guarauna & Accipiter bicolor pileatus & A. guarauna \\
\hline Body length & $23-38 \mathrm{~mm}$ & $11 \mathrm{~mm}$ & $23-38 \mathrm{~mm}$ & $17 \mathrm{~mm}$ & 26 mm \\
\hline Body width & $1.56-3.12 \mathrm{~mm}$ & $3 \mathrm{~mm}$ & $1.56-3.12 \mathrm{~mm}$ & $1.49 \mathrm{~mm}$ & $5 \mathrm{~mm}$ \\
\hline Forebody & ---- & ---- & ----- & ---- & $2.8 \mathrm{~mm}$ \\
\hline Collar head length & \multirow{2}{*}{$1560-3120$} & ---- & ----- & ---- & 1343 \\
\hline Collar head width & & ---- & ----- & ----- & 2580 \\
\hline Angle spines & $190-292 \times 50-116$ & ----- & ----- & ----- & $\begin{array}{c}193-260 \times 73-90 \\
(222 \times 85) \\
106-174 \times 58-72\end{array}$ \\
\hline $\begin{array}{l}\text { Lateral spines } \\
\text { Dorsal spines }\end{array}$ & $150-231 \times 54-108$ & ---- & ---- & ---- & $\begin{array}{c}(134 \times 63) \\
92-101 \times 53-59 \\
(97 \times 55)\end{array}$ \\
\hline Oral sucker length & \multirow{2}{*}{$369-730 \varnothing$} & \multirow{2}{*}{$330 \varnothing$} & \multirow{2}{*}{$369-730 \varnothing$} & 160 & 474 \\
\hline Oral sucker width & & & & 170 & 619 \\
\hline Ventral sucker length & \multirow{2}{*}{$936-1875 \varnothing$} & 1090 & \multirow{2}{*}{$936-1875 \varnothing$} & 840 & 1886 \\
\hline Ventral sucker width & & 1060 & & 730 & 2286 \\
\hline Pharynx length & 616 & 320 & 616 & 160 & 580 \\
\hline Pharynx width & 462 & 160 & 462 & 120 & 261 \\
\hline Oesophagus & $740-1040$ & 610 & $780-1040$ & 750 & 967 \\
\hline Ovary length & \multirow{2}{*}{$520-560 \varnothing$} & 420 & ---- & ---- & 725 \\
\hline Ovary width & & 280 & ----- & ---- & 677 \\
\hline Anterior testis length & $1350-2600$ & $1150-1190$ & ----- & ---- & 2064 \\
\hline Anterior testis width & $325-361$ & 280 & ----- & ----- & 287 \\
\hline Posterior testis length & $1350-2600$ & $1150-1190$ & ----- & ----- & 2150 \\
\hline Posterior testis width & $325-361$ & 280 & ----- & ---- & 287 \\
\hline Cirrus-sac length & $460-650$ & ----- & ----- & ----- & 629 \\
\hline Cirrus-sac width & $277-430$ & ----- & ----- & ---- & 484 \\
\hline Egg-length & $91-109$ & 87 & 109 & ----- & 101 \\
\hline Egg-width & $54-61$ & 54 & 61 & ---- & 48 \\
\hline $\mathrm{Ae}-\mathrm{Ov}$ & ----- & ---- & ----- & ---- & 14 \\
\hline $\mathrm{Ae}-\mathrm{V} v$ & ---- & ---- & ---- & ----- & 2.8 \\
\hline BW (\%) & $6.8-8.2^{*}$ & $27.3^{*}$ & $6.8-8.2^{*}$ & $8.8^{*}$ & 19.2 \\
\hline Fo $(\%)$ & ---- & ---- & ---- & ---- & 10.8 \\
\hline Ov $(\%)$ & $1.5-2.3^{*}$ & $3.8^{*}$ & $1.5-2.3^{*}$ & ----- & 3 \\
\hline $\mathrm{T}(\%)$ & ---- & ---- & ---- & ---- & 19.2 \\
\hline $\mathrm{Os} / \mathrm{Ph}$ & $0.6-1.3^{*}$ & $0.5^{\star}$ & $0.6-1.3^{*}$ & ---- & 0.4 \\
\hline $\mathrm{Vs} / \mathrm{Os}$ & $0.4^{*}$ & $0.3^{*}$ & $0.4^{*}$ & $0.2^{*}$ & 0.3 \\
\hline
\end{tabular}

${ }^{*}$ Calculated from oriainal descriptions. See Table 2 for abbreviations

Comments: Athesmia heterolecithodes is almost a cosmopolitan species, described from mammals (procyonids, myocastorids, canids, cebid, callitrichid and pitheciid monkeys, phyllostomid bats, among others) and a wide range of bird species (anseriforms, charadriiforms, cuculiforms, falconiforms, gruiforms, passeriforms, pelecaniforms, strigiforms and tinamiforms) (Ewing et al., 1968; Travassos et al., 1969; Hammond, 1972; LamotheArgumedo \& Jaimes Cruz, 1982; Martínez, 1985; Martínez \&
Binda, 1992; Tantalean et al., 1990; Digiani, 2000; Lunaschi \& Drago, 2007 a, b, 2009; Vieira et al., 2008). In Argentina, A. heterolecithodes was found parasitizing the bile ducts of Plegadis chihi (Vieillot) (Threskiornithidae), Jacana jacana jacana (L.) (Jacanidae), Vanellus chilensis cayannensis (Gmelin) (Charadriidae), Aramides ypecaha (Vieillot) (Rallidae) and Nothura maculosa (Temminck) (Tinamidae) from Buenos Aires Province, Milvago chimachima (Vieillot) (Falconidae), Rostrhamus sociabilis 
(Vieillot) (Accipitridae) and Guira guira (Gmelin) (Cuculidae) from Formosa Province.

The finding of $A$. heterolecithodes parasitizing $T$. caudatus and $C$. cristata represents two new host records.

Family Stomylotrematidae Poche, 1926

Genus Stomylotrema Looss, 1900

Stomylotrema vicarium Braun, 1901

\section{Taxonomic summary}

Host: Theristicus caudatus (Boddaert) (Buff-necked Ibis) (Pelecaniformes, Threskiornithidae).

Infection site: cloaca.

Intensity of infection: 2.

Voucher material: MLP-He 6790.

Comments: The adult forms of $S$. vicarium were found naturally parasitizing the intestine and cloaca of a wide range of host birds: Theristicus caerulescens (Vieillot) (Threskiornithidae), Ciconia maguari (Gmelin) and Jabiru mycteria (Lichtenstein) (Ciconiidae) from Brazil; Egretta caerulea (L.) (Ardeidae) and Tachybaptus dominicus (L.) (Podicipedidae) from Cuba, and Larus dominicanus Lichtenstein (Laridae), Busarellus nigricollis (Latham) and Buteogallus meridionalis (Latham) (Accipitridae) from Argentina (Braun, 1901; Travassos, 1922, 1928; Szidat, 1964; Travassos et al., 1969; Macko et al., 1999; Lunaschi \& Drago, 2009). Also, Vanellus chilensis (Molina) (as Belonopterus cayennensis) (Charadriidae) and Gallus gallus domesticus (L.) (Phasianidae) were reported as experimental hosts by Ostrowski de Núñez (1978). On the other hand, Travassos \& Freitas (1940) reported an undetermined species of Stomylotrema parasitizing $T$. caudatus. Consequently, T. caudatus represents a new host record for S. vicarium.

Acanthocephala

Family Centrorhynchidae Van Cleave, 1916

Genus Centrorhynchus Lühe, 1911

Centrorhynchus guira Lunaschi \& Drago, 2010

\section{Taxonomic summary}

Host: Theristicus caudatus (Boddaert) (Buff-necked Ibis) (Pelecaniformes, Threskiornithidae).

Infection site: small intestine.

Intensity of infection: 34 .

Voucher material: MLP-He 6791.

Comments: This species was recently described by Lunaschi \& Drago (2010) parasitizing the American Striped Cuckoo, G. guira from the same locality. The morphology and measurements of specimens obtained from $T$. caudatus are within the range of variability stated for this species.

The finding of $C$. guira in $T$. caudatus represents a new host record.

\section{Discussion}

The diet of $T$. caudatus is mainly composed of arthropods (insects, spiders, centipedes), amphibians, small reptiles, and occa- sionally small mammals, snails and other small invertebrates found in soft soils (Matheu \& del Hoyo, 1992). Three parasitic species, S. vicarium, C. guira and $A$. heterolecitodes were recovered in this host bird. The first two species were found exclusively in this bird species, and the latter, also in C. cristata. The partial life cycle of $S$. vicarium in Argentina was elucidated from naturally encysted metacercariae found in the visceral cavity of larvae of Megadytes glauca Brullé, 1837 (Coleoptera, Dityscidae), and the adults were experimentally obtained from $V$. chilensis and G. g. domesticus (Ostrowski de Núñez, 1978). Moreover, this author believes that virgule-cercariae that emerged from Pomacea canaliculata (Lamarck) (as Ampularia c.) could correspond to the metacercariae found in the larvae of $M$. glauca. Digiani (2002) and Amato and Amato (2006) reported Belostoma oxyurum (Dufour), Belostoma foveolatum (Mayr) and Belostoma dilatatum (Dufour) (Hemiptera, Belostomatidae) from Argentina and Brazil, respectively, as natural second intermediate hosts of this species. Theristicus caudatus can acquire this digenean by ingesting aquatic arthropods infected with metacercariae. The life cycle of $C$. guira, is unknown, however Centrorhynchus spp. uses birds and mammals as definitive hosts, terrestrial isopods or insects as intermediate hosts, and amphibious, reptiles or insectivorous mammals as transport or paratenic hosts. In the Neotropical Region, Amato et al. (2003) reported cystacanths of Centrorhynchus from Brazil parasitizing terrestrial isopods, Atlantoscia floridana (van Name) (Crustacea, Isopoda) as first intermediate host. In contrast, cystacanths of Centrorhynchus in paratenic hosts have been reported in several occasions, such as cysts of Centrorhynchus tumidulus Rudolphi, 1919 in the body cavity of Ameiva ameiva (L.), Tupinambis teguixin L. (Squamata, Teiidae) and Tropidurus torquatus (Wied-Neuwied) (Squamata, Tropiduridae) from Brazil; cystacanths of Centrorhynchus sp. in Atelopus bomolochus Peters (Anura: Bufonidae) from Perú, in $T$. teguixin from Paraguay, in Rhinella fernandezae (Gallardo) (Anura, Bufonidae) from Brazil, in Eupsophus calcaratus (Günther) and Eupsophus roseus (Duméril \& Bibron) (Anura, Leptodactylidae) from Chile, and Leptodactylus diptyx (Boettger), Leptodactylus bufonius Boulenger (Anura: Leptodactylidae), Leptophis ahaetulla marginatus (Cope) (Squamata, Colubridae) and cystacanths of $C$. guira in the Maned Wolf, Chrysocyon brachyurus Illiger (Carnivora, Canidae) from Argentina (Vizcaíno, 1993; Torres \& Puga, 1996; Puga \& Torres, 1999; Amato et al.,2003; lannacone, 2003; Lamas \& Lunaschi, 2009; Ávila \& Silva, 2010; dos Santos \& Amato, 2010; Hamann et al., 2012; Zaracho et al., 2012; González et al., 2013). Then, T. caudatus probably acquire infestations of adult acanthocephalan by consumption of amphibious or reptiles infected with cystacanths.

The complete life cycle of $A$. heterolecitodes is unknown, but as a representative of Dicrocoeliidae, it should fulfil its biological cycle with the participation of pulmonate snails as first intermediate host. The cercariae may encyst as metacercariae in the mollusc, or in several species of arthropods and lizards, which act as second intermediate hosts (Patten, 1952). Theristicus caudatus and C. cristata have similar feeding habits given that C. cristata also feeds on large insects (Orthoptera), snakes and lizards (Di Giacomo, 2005). Therefore, probably both bird species can acquire A. heterolecitodes by eating insects and small reptiles, which act as potential intermediate hosts of this digenean species. 
The diet of $A$. guarauna is mainly composed of apple snails, Pomacea spp. (Ampullariidae), and occasionally mussels, lizards, and variety of other small prey (Bryan, 1996). This host species was found parasitized by two echinostomatid species, L. lyperorchis and E. serrata, and so far, their life cycles have not been elucidated. The echinostomatids have mainly freshwater snails as first and second intermediate hosts and, to a lesser extent in tadpoles, fishes and annelids as second intermediate hosts. This allows us to suppose that $A$. guarauna, may become infested by ingesting metacercariae encysted in $P$. canaliculata and/or Pomacea scalaris (d'Orbigny), which are abundant in the study area.

Finally, $S$. sibilatrix is almost exclusively insectivorous, with a preference for consumption of arthropods, especially insects such as grasshoppers, and can feed on small vertebrates as amphibians, lizards, and snakes (Franz et al., 2007). This host was found parasitized by $N$. limai which, as the previously mentioned echinostomatids, have mainly freshwater snails as first and second intermediate hosts and, to a lesser extent, frog tadpoles, fishes and annelids as second intermediate hosts. In this context, Hamann et al. $(2006,2010)$ reported the occurrence of metacercariae of Nephrostomum sp. encysted in the liver of Leptodactylus chaquensis Cei (Anura, Leptodactylidae) and Scinax nasicus (Cope) (Anura, Hylidae) from Corrientes Provin$\mathrm{ce}$, Argentina. These frog species have been recorded in the $\mathrm{EI}$ Bagual Ecological Reserve by Lavilla (2005), and therefore may have been the way of infection of $S$. sibilatrix with $N$. limai.

\section{Acknowledgments}

The authors wish to thank Mr. Luis Pagano for his assistance in collecting the hosts. Special thanks are due to Dr. Carlos Montoya for help and hospitality during our stay in La Marcela farm, Formosa Province. The authors, Lía Lunaschi and Regina Draghi are members of the Comisión de Investigaciones Científicas de la Provincia de Buenos Aires $(\mathrm{CIC})$ and Fabiana Drago is member of Universidad Nacional de La Plata (UNLP). The present study was funded by CIC (Res. № 2410/12) and UNLP (11/N603).

\section{References}

Amato, J.F.R., Amato, S.B., ARAuJO, P.B., QuAdRos, A.F. (2003): First report of pigmentation dystrophy in terrestrial isopods, Atlantoscia floridana (van Name) (Isopoda, Oniscidea), induced by larval acanthocephalans. Rev. Bras. Zool., 20(4): 711 - 716. DOI: 10.1590/S0101-81752003000400026

AмAто, S.B., AмAто, J.F.R. (2006): Belostoma dilatatum (Dufour) (Hemiptera, Belostomatidae) hosting metacercariae of Stomylotrema vicarium Braun (Digenea, Stomylotrematidae) in southern Brazil. Rev. Bras. Zool., 23(1): 307 - 310. DOI: 10.1590/S010181752006000100028

ARRUdA, V.S., PINTO, R.M., Muniz-PEREIRA, L.C. (2001): New host and geographical records for helminths parasites of Ardeidae (Aves, Ciconiiformes) in Brazil. Rev. Bras. Zool., 18(1): 225 - 232 ÁvILA, R.W., SILVA, R.J. (2010): Checklist of helminths from lizards and amphisbaenians (Reptilia, Squamata) of South America. J. Venom. Anim. Toxins incl. Trop. Dis., 16(4): 543 - 572. DOI: 10.1590/S1678-91992010000400005
BARRETO, A.L. (1919): On the Brazilian Species of the Sub-family Subulurinae Travassos, 1914. Mem. Inst. Oswaldo Cruz, 11(1): 10 - 70. DOI: $10.1590 / S 0074-02761919000100002$

BoERO, J.J., LED, J.E. (1968): El parasitismo de la fauna autóctona. III. Los parásitos de las aves argentinas. Rev. Fac. Cs. Vet., La Plata, 10(22): 97 - 129

BRAUN, M. (1901): Zur Revision der Trematoden der Vögel II. Centralbl. f.Bak.,Abth I, 29: 895 - 897

BRYAN, D.C. (1996): Family Aramidae (Limpkin). In: DEL HoYo, J., Elliot, A., Sargatal, L. (Eds) Handbooks of the Birds of the World. Volume 3. Hoatzin to Auks. Barcelona, Spain: Lynx Editions, pp. $90-95$

CABALleRO, E., DíaZ-UngRíA, C. (1958): Intento de un catálogo de los trematodos digéneos registrados en territorio venezolano. Mem. Soc. Cienc. Nat. La Salle, 18(49): 19 - 36

CONTI, J.A., FORRESTER, D.J., NESBITI, S.A.(1985): Parasites of limpkins, Aramus guarauna, in Florida. P. Helm. Soc. Wash., 52(1): $140-142$

CRISTOFARO, R., FEIJO, L.M.F. (1976): Contribuição ao estudo da faúna helmintológica do Estado de Matto Grosso. Atas Soc. Biol. Rio de Janeiro, 18: 53 - 57

DIETZ, E. (1910): Die Echinostomiden der Vögel. Zool. Jahrb., 12: $265-518$

DI GIACOMO, A.G. (2005): Aves de la Reserva El Bagual. In: DI GIACOMO, A.G., KRAPOVICKAS, S.F. (Eds), Historia natural y paisaje de la Reserva El Bagual, Provincia de Formosa, Argentina Inventario de la fauna de vertebrados y de la flora vascular de un área del Chaco Húmedo. Buenos Aires, Argentina: Aves Argentinas/Asociación Ornitológica del Plata, pp. 201 - 465

DIGIANI, M.C. (1997): Lyperorchis inexpectabilis n. sp. parásita de Aramus guarauna guarauna (L.) (Aves: Aramidae) y reubicación del género Lyperorchis Travassos, 1921 (Digenea: Echinostomatidae). Neotropica, 43: $79-83$

DIGIANI, M.C. (2000): Digeneans and cestodes parasitic in the white-faced ibis Plegadis chihi (Aves: Threskiornithidae) from Argentina. Folia Parasitol., 47: 195 - 204

DIGIANI, M.C. (2002): Belostomatidae (Insecta: Heteroptera) as intermediate hosts of Digenetic Trematodes. Comp. Parasitol., 69(1): 89 - 92. DOI: 10.1654/1525-2647(2002)069[0089:BIHAIH]2.0.CO;2 DIGIANI, M.C., SUTTON, C.A. (2001): New reports and a redescription of Porrocaecum heteropterum (Diesing, 1851) (Ascarididae), a rare nematode parasitic in South American threskiornithid birds. Syst. Parasitol., 49: 1 - 6. DOI: 10.1023/A: 1010730611828

DuBoIS, G. (1981): Notes Hehninthologiques V: Strigeidae Railliet, Diplostomididae Poirier et Proterodiplostomidae Dubois. Rev. Suisse Zool., 88(1): 227 - 232

EWIng, S.A., Helland, D.R., ANTHONY, H.D., LeIPOLD, H.W. (1968): Occurrence of Athesmia sp. in the cinnamon ringtail monkey, Cebus albifrons. Lab. Anim. Care., 18(4): 488 - 492

Franz, I., GHIZONI, I.R., AlbuQUeRQUe, J.L.B., BARCEllos, A., Hassdenteufel, C.B., AREND, F.L., MARTInS-FerReiRA, C. (2007): Predação da cobra d'água Helicops infrataeniatus (Serpentes, Colubridae) pela maria-faceira Syrigma sibilatrix (Aves, Ardeidae) no sul do Brasil. Biotemas, 20(2): 135 - 137

FREITAS, J.F.T., IBÁÑEZ, N.H. (1965): Fauna helmintológica do Peru nova espécie do gênero Ascaridia Dujardin, 1845 (Nematoda, Ascaridoidea) Fuhrmann (1908). Mem. Inst. Oswaldo Cruz, 63: $51-58$ 
FumRmanN, O. (1908): Die Cestoden der Vögel. Zool. Jahrb., 10 (Suppl.): 1 - 232

GeORgIeV, B.B., Vaucher, C. (2000): Chimaerula bonai sp. n. (Cestoda: Dilepididae) from the bare-faced ibis, Phimosus infuscatus (Lichtenstein) (Aves: Threskiornithidae) in Paraguay. Folia Parasitol., 47: $303-308$

GONZÁleZ, C.A., MILANO, A.M.F., LUNASCHI, L.I. (2013). New findings of helminths parasites of Chrysocyon brachyurus (Carnivora: Canidae) in Argentina. Neotrop. Helminthol., 7(2): $265-270$

HAMANN, M.K., KEHR, A.I., GONZÁLEZ, C.E. (2006): Species affinity and infracommunity ordination of helminths of Leptodactylus chaquensis (Anura: Leptodactylidae) in two contrasting environments from Northeastern Argentina. J. Parasitol., 92(6): 1171 - 1179. DOI: 10.1645/GE-862R1.1

HamanN, M.K., KeHR, A.I., GonZÁlEZ, C.E. (2010): Helminth community structure of Scinax nasicus (Anura: Hylidae) from a South American subtropical area. Dis. Aquat. Organ., 93: 71 82. DOI: $10.3354 /$ dao02276

HamanN, M.K., KeHR, A.I., GonzÁlez, C.E. (2012): Community structure of helminth parasites of Leptodactylus bufonius (Anura: Leptodactylidae) from Northeastern Argentina. Zool. Stud., 51(8): $1454-1463$

HAMmOND, J.A. (1972): On Athesmia (Trematoda: Dicrocoeliidae) from Jackals in Tanzania. J. Helminthol., 46(2): 175 - 184. DOI: 10.1017/S0022149X00022276

IANNACONE, J. (2003): Helmintos parasitos de Atelopus bomolochus Peters 1973 (Anura: Bufonidae) de Piura, Perú. Gayana, 67(1): 9 - 15. DOI: 10.4067/S0717-65382003000100002

KostadinOVA, A. (2005): Family Echinostomatidae Looss 1899. In: JONES, A., BRAY, R.A., GIBSON, D.I. (Eds) Keys to the Trematoda.Volume 2. London, UK: CABI Publishing and The Natural History Museum, pp. 9 - 64

LAMAS, M.F., LUNASCHI, L.I. (2009): Ocurrencia de Centrorhynchus sp. (Acantohocephala: Centrorhynchidae) en Leptophis ahaetulla marginatus (Squamata: Colubridae). Cuad. herpetol.,23(1): $45-49$

LAmothe-ARgumedo, R., JaImes CRUZ, B. (1982): Trematoda. Parasitic stages. In: HuRlBert, S.H., Villalobos FigueroA, A. (Eds), Aquatic Biota of Mexico, Central America and the West Indies. San Diego State University, California, pp. 73 - 84

LANGERON, M. (1942): Précis de Microscopie. 6th Edition, Paris, Masson et Cie, 1340 pp.

LAVILLA, E.O. (2005): Anfibios de la Reserva El Bagual. In: DI Giacomo, A.G., KRAPOVICKAS, S.F. (Eds), Historia natural y paisaje de la Reserva El Bagual, Provincia de Formosa, Argentina. Inventario de la fauna de vertebrados y de la flora vascular de un área del Chaco Húmedo. Buenos Aires, Argentina: Aves Argentinas/Asociación Ornitológica del Plata, pp. 119 - 153 LUNASCHI, L.I., DRAGO, F.B. (2007a): Checklist of digenean parasites of birds from Argentina. Zootaxa, 1403: 1 - 36

LUNASCHI, L.I., DRAGO, F.B. (2007b): Checklist of digenean parasites of wild mammals from Argentina. Zootaxa, 1580: 35 - 50 LUNASCHI, L.I., DRAGO, F.B. (2009): Digenean parasites of six species of birds from Formosa Province, Argentina. Rev. Mex. Biodivers., 80(1): $39-46$

LUNASCHI, L.I., DRAGO, F.B. (2010): A new species of Centrorhynchus (Acanthocephala, Centrorhynchidae) endoparasite of Guira guira (Aves, Cuculidae) from Argentina. Helminthologia, 47(1): 38 - 47. DOI: $10.2478 / \mathrm{s} 11687-010-0007-x$

LUNASCHI, L.I., DRAGO, F.B. (2012): Digenean parasites of Cariama cristata (Aves: Gruiformes) from Formosa Province, Argentina, with the description of a new species of the genus Strigea. Acta Parasitol., 57(1): 26 - 33. DOI: 10.2478/s11686012-0004-y

LUTZ, A. (1928): Estudios de zoología y parasicología Venezolana. Rio de Janeiro, 133 pp.

MACKO, J.K., ŠPAKULOVÁ, M., CASANOVA, J.C. (1999): Morphology and taxonomy of Stomylotrema (Digenea: Stomylotrematidae) representatives from ciconiiform and podicipediform birds in Cuba. Folia Parasitol., 46: 185 - 190

MAGALHÃES PINTO, E.,VICENTE, J.J. (1995): Tetrameres (Tetrameres) spirospiculum n. sp. (Nematoda, Tetrameridae) from the Buffnecked Ibis, Theristicus caudatus caudatus (Boddaert) (Aves, Threskiornithidae). Mem. Inst. Oswaldo Cruz, 90(5): 615 - 617 MARTíneZ, F.A. (1985): Athesmia foxi Goldberger y Crane, 1911 (Trematoda-Dicrocoeliidae) en Pseudalopex gymnocercus de Argentina. Vet. Argent., 2: $875-878$

MARTíneZ, F.A., BINDA, J.L. (1992): Athesmia heterolecithodes (Braun, 1899) Looss, 1899 (Trematoda, Dicrocoeliidae) en Myocastor coypus. Vet. Argent., 9: $98-101$

MAsI PAllares, R., Benítez USHER, C. (1972): Algunos Helmintos en Aves en Paraguay. Rev. Paraguaya Microbiol., 7(1): 33 - 63

MATHEU, E., DEL Hoyo, J. (1992): Family Thereskionithidae. In: DEL Hoyo, J., ElLIOT, A., SARGatal, S. (Eds) Handbooks of the Birds of the World. Volume 1. Ibises and Spoonbills. Barcelona, Spain: Lynx Editions, pp. 472 - 506

NASIR, P., DíAz, M.T. (1972): Avian flukes of Venezuela. Riv. Parassitol., 33(4): $245-276$

Noronha, D., SÁ, M.R., Knoff, M., Muniz-PereiRA, L.C., PInTO, R.M. (2009): Adolpho Lutz e a Coleção Helmintológica do Instituto Oswaldo Cruz, Rio de Janeiro, Brazil, Museu Nacional, 154 pp.

OSTROWSKI DE NúÑEZ, M. (1978): Zum Entwicklungszyklus von Stomylotrema vicarium. Angew. Parasitol., 19: 208 - 213

ÖZDIKMEN, H. (2013): Substitute names for two preoccupied genus group names in Trematoda (Platyhelminthes). Mun. Ent. Zool., 8(1): $475-476$

PAtTEN, J.A. (1952): The life cycle of Conspicuum icteridorum Denton and Byrd, 1951, (Trematoda: Dicrocoeliidae). J. Parasitol., 38(2): 165 - 182

PÉrez Vigueras, I. (1944): Trematodes de la Superfamilia Echinostomatoidea, con descripción de siete especies nuevas de Cuba. Rev. Univ. Habana, 55 - 57: 1 - 23

Pérez Vigueras, I. (1956): Contribución al conocimiento de la fauna helmintológica cubana. Mem. Soc. Cubana. Hist. Nat., 23 $(1-2): 1-36$

PugA, S., TORRES, P. (1999): Helminths parasites of Eupsophus roseus (Anura: Leptodactylidae) from Southern Chile. Mem. Inst. Oswaldo Cruz, 94(6): 725 - 726. DOI: 10.1590/S0074-027619 99000600003

RANSOM, B.H. (1904): Manson's eye worm of chickens (Oxyspirura mansoni), with a general, review of nematodes parasitic in the eyes of birds. U.S.D.A Bureau Animal Industry Bull., 60: $7-54$

Remsen, J.V., Cadena, C.D., Jaramillo, A., Nores, M., Pacheco, J.F., PÉreZ-EmÁn, J., RobBins, M.B., StILES, F.G., STOTZ, D.F., ZIM- 
MER, K.J. (2014): A classification of the bird species of South America. American Ornithologists' Union. Retrieved August 24, 2014 from http://www.museum.Isu.edu/ Remsen/SACCBaseline.html SERGIENKO, M.I. (1970): A new species of echinostomatids, Prionosoma zachwatkini n. sp. Parazitologiya, 4(4): 327 - 329 SCHULTZ, R.L. (1939): A new tapeworm from Swainson's Hawk. Trans. Am. Microsc. Soc., 58(4): $448-451$

Spalding, M.G., KINSElLA, J.M., NesBitT, S.A., FolK, M.J., FosteR, G.W. (1996): Helminth and arthropod parasites of experimentally introduced whooping cranes in Florida. J. Wildl. Dis., 32(1): $44-50$

Su, Y.C., FEl, C.Y. (2000): Endoparasitic helminths of Ardeidae birds in Taiwan. [Abstract] Asia Seasonly Report of Environmental Microbiology, 9: 11 - 18. Retrieved August 19, 2013 from CAB Direct http://www.cabdirect.org/abstracts/

SUTTON, C.A., LUNASCHI, L.I., TOPA, P.A. (1982): Fauna helmintológica de las aves del Lago Pellegrini. I. Trematoda-Echinostomatidae en Podiceps major (Boddaert), Rollandia rolland (Quoy \& Gaymard) y Bubulcus ibis (Linné). Limnobios, 2(5): 336 - 341

SzIDAT, L. (1964): Vergleinchende Helmintologische Untersuchungen an den Argentinischen Grössmowen Larus marinus dominicanus Lichtenstein und Larus ridibundus maculipennis Lichtenstein Nebst Neuen Beobachtungen uber die Artbildung bei Parasiten. Z. Parasitenk., 24: $351-414$

Tantalean, M., Gozalo, A., Montoya, E. (1990): Notes on Some Helminth Parasites from Peruvian Monkeys. Lab. Primate Newsletter, 29 (2): 6 - 9

TORRES, P., PugA, S. (1996): Occurrence of cystacanths of Centrorhynchus sp. (Acanthocephala: Centrorhynchidae) in toads of the genus Eupsophus in Chile. Mem. Inst. Oswaldo Cruz, 91(6): 717 - 719. DOI: 10.1590/S0074-02761996000600011

TRAVASSOS, L. (1917): Contribuições para o conhecimento da fauna helmintológica brasileira. Mem. Inst. Oswaldo Cruz, 9(1): 5 - 59 TRavassos, L. (1921): Trematódeos novos III. Brazil Medico, 1(18): $221-222$
TRAVASSOS, L. (1922): Informações sobre a fauna helmintológica de Matto Grosso. A. Folha Medica, 3(24): 187 - 190

TRAVASSOS, L. (1928): Fauna Helmintológica de Matto Grosso. Mem. Inst. Oswaldo Cruz 21(2): 309 - 354. DOI: 10.1590/S007402761928000200002

TRAVASSOS, L. (1938): Informações sobre a fauna helmintológica de Matto Grosso. Trematoda II. Mem. Inst. Oswaldo Cruz, 33(4): 461-484. DOI: 10.1590/S0074-02761938000400002

TRAVASSOS, L., FREITAS, J.F.T. (1940): II. Pesquisas Helmintológicas. Mem. Inst. Oswaldo Cruz, 35(3): 610 - 633. DOI: 10.1590/S0074-02761940000300013

TRAVASSOS, L., FREITAS, J.F.T., KoHN, A. (1969): Trematódeos do Brasil. Mem. Inst. Oswaldo Cruz, 67: 1 - 886 pp.

VIANA, L. (1924): Tentativa de catalogação das especies brazileiras de trematódeos. Mem. Inst. Oswaldo Cruz, 17(1): 95 - 228

ViCENTE, J.J., MAgalhaEs PINTO, R., NORONHA, D., GONÇALVES, L. (1995a): Nematode parasites of Brazilian Ciconiiformes birds: a general survey with new records for the species. Mem. Inst. Oswaldo Cruz, 90: 389 - 393

VICENTE, J.J., RODRIgues, H. DE O., CORRÊA GOMES, D., MAgalhães PINTO, R. (1995b): Nematóides do Brasil. Parte IV: Nematóides de aves. Rev. Bras. Zool., 12: 1 - 273

VIEIRA, F.M., LUQUE, J.L., MUNIZ-PEREIRA, L.C. (2008): Checklist of helminth parasites in wild carnivore mammals from Brazil. Zootaxa, 1721: 1 - 23

VizCAínO, S.I. (1993): Presencia del género Centrorhynchus Lühe, 1911, (Acanthocephala: Centrorhynchidae) en la República Argentina. Neotropica, 39(10 1-102): 77 - 78

YamaguTI, S. (1961): Systema Helminthum. Volume 3. The Nematodes of Vertebrates. Interscience Publishers, Inc., New York, $1261 \mathrm{pp}$.

ZARACHO, V.H., AcOSTA, J.L., LAMAS, M.F. (2012): Dieta y parasitismo de Leptodactylus diptyx (Anura: Leptodactylidae) del nordeste argentino. Rev. Mex. Biodivers., 83(4): 1180 - 1186. DOI: $10.7550 / \mathrm{rmb} .28251$ 